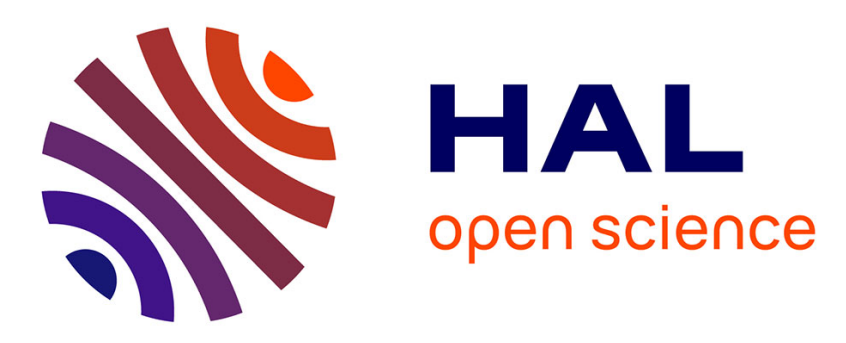

\title{
The natural compounds atraric acid and N-butylbenzene-sulfonamide as antagonists of the human androgen receptor and inhibitors of prostate cancer cell growth
}

Daniela Roell, Aria Baniahmad

\section{To cite this version:}

Daniela Roell, Aria Baniahmad. The natural compounds atraric acid and N-butylbenzene-sulfonamide as antagonists of the human androgen receptor and inhibitors of prostate cancer cell growth. Molecular and Cellular Endocrinology, 2010, 332 (1-2), pp.1. 10.1016/j.mce.2010.09.013 . hal-00654968

\author{
HAL Id: hal-00654968 \\ https://hal.science/hal-00654968
}

Submitted on 24 Dec 2011

HAL is a multi-disciplinary open access archive for the deposit and dissemination of scientific research documents, whether they are published or not. The documents may come from teaching and research institutions in France or abroad, or from public or private research centers.
L'archive ouverte pluridisciplinaire HAL, est destinée au dépôt et à la diffusion de documents scientifiques de niveau recherche, publiés ou non, émanant des établissements d'enseignement et de recherche français ou étrangers, des laboratoires publics ou privés. 


\section{Accepted Manuscript}

Title: The natural compounds atraric acid and N-butylbenzene-sulfonamide as antagonists of the human androgen receptor and inhibitors of prostate cancer cell growth

Authors: Daniela Roell, Aria Baniahmad

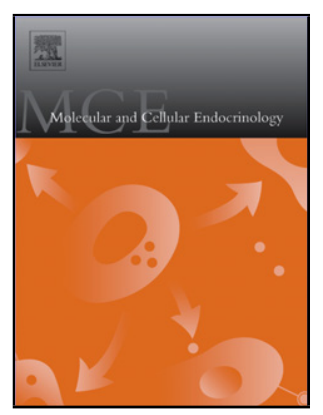

PII:

S0303-7207(10)00474-0

DOI: doi:10.1016/j.mce.2010.09.013

Reference: MCE 7644

To appear in: $\quad$ Molecular and Cellular Endocrinology

Received date: $\quad 29-6-2010$

Revised date: $\quad 3-9-2010$

Accepted date: $\quad$ 27-9-2010

Please cite this article as: Roell, D., Baniahmad, A., The natural compounds atraric acid and N-butylbenzene-sulfonamide as antagonists of the human androgen receptor and inhibitors of prostate cancer cell growth, Molecular and Cellular Endocrinology (2010), doi:10.1016/j.mce.2010.09.013

This is a PDF file of an unedited manuscript that has been accepted for publication. As a service to our customers we are providing this early version of the manuscript. The manuscript will undergo copyediting, typesetting, and review of the resulting proof before it is published in its final form. Please note that during the production process errors may be discovered which could affect the content, and all legal disclaimers that apply to the journal pertain. 


\title{
The natural compounds atraric acid and N-butylbenzene- sulfonamide as antagonists of the human androgen receptor and inhibitors of prostate cancer cell growth
}

Daniela Roell and Aria Baniahmad*

Institute of Human Genetics, Jena University Hospital, D-07743 Jena, Germany

* Corresponding author

Phone: $+49-3641-935501$

FAX: $+49-3641-935502$

Email: aban@mti.uni-jena.de

\begin{abstract}
Extracts from the plant Pygeum africanum are widely used in the therapy of benign prostate hyperplasia (BPH) and in combinational therapy for prostate cancer, the second leading cause of cancer death and the mostly diagnosed form of cancer in men. The androgen receptor (AR) plays a crucial role in the development of the prostate as well as in prostate diseases. Even though the extracts from Pygeum africanum are considered as beneficial for prostate diseases in clinical trials, and some active compounds for treatment of BPH could be identified, compounds responsible for AR inhibition and the molecular mechanism for inhibition of prostatitis need to be identified. Recently, atraric acid and N-butylbenzenesulfonamide were isolated from a selective dichlormethane extract of Pygeum africanum as two novel AR antagonistic compounds. The molecular mechanisms of AR inhibition were analyzed and are summarized here. Both compounds are the first known natural, complete and specific AR antagonist.
\end{abstract}


Key Words: Prunus africanus, Prunus africana, natural compound, antihormone, antagonist, co-repressor

\section{Content}

1. Introduction

2. Pygeum africanum

3. The natural compounds AA and NBBS

4. Insights in the molecular mechanism of AA and NBBS

5. Discussion

6. References

\section{Introduction}

Prostate cancer $(\mathrm{PCa})$ is one of the major health problems in elderly men and one of the most often diagnosed malignancies. In western countries it even emerged as the second leading cause of cancer death for men (Edwards et al., 2010). As a non-malignant form of prostate diseases benign prostate hyperplasia $(\mathrm{BPH})$ is also a very common disease affecting aging males with sometimes severe influence for quality of life (Shah et al., 2004). $\mathrm{BPH}$ is associated with bothersome lower urinary tract symptoms by interfering with normal daily activities and sleep patterns (Skolarikos et al., 2004). Both prostatic diseases, BPH and $\mathrm{PCa}$, are characterized by the progressive enlargement of the prostate.

The androgen receptor (AR) plays an important role in the development of the prostate and in the development and progression of prostatic diseases like BPH and PCa. The AR is a nuclear hormone receptor that can be activated by androgens like testosterone and dihydrotestosterone (DHT) (Tenbaum et al., 1997). The AR consists of an amino-terminal domain harbouring a potent transactivation function, followed by a DNA-binding domain and 
a carboxy-terminal ligand binding domain. After androgen binding a conformational change of the AR is induced, followed by the translocation into the nucleus and the binding to androgen response elements of AR target genes. Hence, the AR acts as a transcription factor to transactivate or to inhibit gene expression. The transcriptional properties of the AR are partly dependent on binding of co-regulators (co-activators and co-repressors) (Brinkmann et al.,1999; Burke and Baniahmad, 2000; Rosenfeld et al. 2001; Feldman et al., 2001; Papaioannou et al., 2005; Baniahmad, 2005).

In general, co-repressors (CoR) have been identified as cofactors required for targeting gene repression by those transcription factors having a silencing function (Burke and Baniahmad, 2000). Although, many CoR for the AR have been identified (Wang et al., 2005), a silencing domain for AR has not yet been described. CoR including those that bind to the silencing domain of the thyroid hormone receptor such as SMRT (silencing mediator for RAR and TR), NCoR (nuclear receptor co-repressor) and Alien interact with the AR. In these studies the Nterminus of the AR was determined as the interacting region, the region of the receptor that also interacts with co-activators (Dotzlaw et al., 2002; 2003; Hodgson et al., 2005).

As the AR is the main effector of PCa cell proliferation and progression (Brinkman et al., 2000; Ntais et al., 2003) the inhibition of the AR plays an important goal in PCa therapy. A common treatment of $\mathrm{PCa}$ is the combination of hormone-ablation and treatment with $\mathrm{AR}$ antagonists (antihormones). Interestingly, CoR inhibit AR-mediated transactivation in the presence of specific currently therapeutically used androgen agonists (Dotzlaw et al., 2002). One can differentiate between pure antagonists and mixed agonists/antagonists also termed partial antagonists (Migliari et al., 1999). The pure AR-antagonists such as casodex or hydroxyflutamide $(\mathrm{OH}-\mathrm{Fl})$ are non-steroidal compounds that allow the recruitment of CoR to the AR and inhibit its activity as well as the PCa proliferation (Dotzlaw et al., 2002; Song et al., 2004; Papaioannou et al., 2005; Baniahmad et al., 2005; Powell et al., 2006). Also the cellular distribution of the AR seems to be changed by these ligands (Tyagi et al., 2000; Farla et al., 2005; Marcelli et al., 2006; Nakauchi et al., 2007). The partial AR antagonist 
cyproterone acetate (CPA), which is a steroidal compound, represses the AR-mediated transactivation but exhibits also partial agonistic activity by partially activating the ARmediated transactivation. The level of CPA-mediated repression of AR is strictly dependent on the presence of CoR (Dotzlaw et al., 2002; 2003), indicating that antihormone therapy of $\mathrm{PCa}$ is successful in the presence of functional CoR.

Interestingly, pure and partial antagonists show a different recruitment pattern of CoR on androgen response elements (ARE). In the presence of casodex the AR CoR SMRT is recruited to the prostate specific antigen (PSA) promoter but not to the mouse mammary tumor virus promoter (MMTV), containing several AREs, whereas in the presence of CPA SMRT is recruited to the MMTV promoter (Dotzlaw et al., 2002; Shang et al., 2002; Kang et al., 2004). Also differences of recruitment among CoR can be observed on various AREs (Papaioannou et al., 2005 and unpublished data). These results indicate that the CoR recruitment is on one hand dependent on the ARE of the target gene, suggesting a structural influence of the DNA and on the other hand on the type of ligand. A possible explanation is that a specific AR structure is imposed by both the type of ligand and the DNA sequence of a particular ARE that dictates binding specificity of CoR to the AR (Papaioannou et al., 2005). A further complexity emerges by observations that the interaction of CoR with the AR in the presence of partial antagonists can also be regulated through competition with co-activators. Using CPA a co-activator/CoR competition was observed and interestingly an increasing expression of either CoR or co-activator shifts the AR towards a more repressed or activated state, respectively (Papaioannou et al., 2005).

Thus, at present in PCa therapy only non-steroidal compounds are generally known as pure AR antagonists and CPA represents a steroidal compound that exhibits mixed agonist/antagonist activity. One major molecular mechanism seems to be that these compounds require CoR-mediated repression of $A R$ target genes.

However, antihormone treatment is effective only for a limited period of about 16-24 months after which PCa becomes androgen-independent (Feldman et al., 2001; Eisold et al., 2009). 
Different mechanisms seem to be involved in this process e.g. a shifted co-activator-CoR ratio (Balk, 2002). (I) CoR may have lost the ability to repress the AR, possibly due to CoR modification e.g. phosphorylation by activation of mitotic signaling pathways (Baniahmad et al., 2005), (II) an overexpression of the AR that leads to titration of CoR (Chen et al., 2004), or (III) mutation of the AR (Denmeade et al., 2001) that might induce an AR conformation leading to AR-mediated transactivation. Unfortunately, some of the occurring AR mutations during PCa progression render therapeutically used antiandrogens into AR agonists (Farla et al., 2005). In consequence those therapeutics then become useless even disadvantageous because they can promote PCa progression.

Radical prostatectomy or local irradiations are other option for PCa therapy if the carcinoma is limited to the prostatic tissue (Cato et al., 2002). Nevertheless the surgery of the prostate often leads to side effects like incontinence, impotence and marks psychological problems for most men. Additionally men developing PCa are in most cases seniors for which a surgery and the anesthesia is buried with threat.

PCa as well as BPH are also treated with inhibitors (e.g. finasteride) of the $5 \alpha$-reductase, the enzyme that converts testosterone into its more active metabolite DHT (Levin and Das, 2000). A decrease of the total level of androgens and a shrinkage of the prostate are the consequence (Levin and Das 2000). Finasteride only targets one of the two isoforms of the $5 \alpha$-reductase and therefore is not sufficient to block androgens levels, especially in advanced PCa (Vis and Schröder, 2009).

The luteinizing hormone releasing hormone $(\mathrm{LHRH})$ is manly responsible for the synthesis of testosterone. Therefore $\mathrm{LHRH}$ analoga decrease the amount of $\mathrm{LHRH}$ receptors and in consequence lead to a down-regulation of the androgen-production (Corbin 1982). However, also the adrenal gland produces a remarkable amount of androgen that also acts in the prostate. In this case LHRH-analoga fail their function. Thus, LHRH-analoga are mostly combined with antiandrogens for the treatment of $\mathrm{PCa}$ to reach a complete blockage of hormone activity (Fuhrman et al., 1998; Labrie et al., 1989) 
Besides treatment of $\mathrm{PCa}$ and prostatic diseases with the above described therapies the treatment with plant extracts is a common therapy (Dreikorn, 2002; Schleich et al., 2006b). Phytotherapeutic agents represent nearly half of the medications dispensed for BPH in Italy, compared to $5 \%$ for alpha blockers and $5 \%$ for $5 \alpha$-reductase inhibitors and in Germany and Austria phytotherapy is the first-line treatment for mild to moderate urinary obstructive symptoms and represent $29 \%$ of all drugs described for the treatment of BPH (Wilt and Ishani, 2002). Even though those plant extracts are considered as beneficial for BPH and PCa only few of the active compounds have been characterised and none were shown to bind directly to the AR.

\section{Pygeum africanum}

The evergreen tree Pygeum africanum is distributed across the entire African continent in mountain regions. It is also known as Prunus africana or Prunus africanus, a member of the Rosaceae family. Its bark is traditionally used to treat chest pain, malaria and fevers (Bombardelli et al., 1997). European travellers became interested in this tree when they learned in the 1700s from South African tribes how to treat bladder discomfort and the "old man's disease" with the bark (Simons et al., 1998). As this plant seemed to have many effects on different diseases some of its active components had been isolated and investigated. The active compounds include phytosterols (e.g. beta-sitosterol) that have antiinflammatory effects by inhibiting the production of pro-inflammatory prostaglandins and pentacyclic triterpenes (e.g. ursolic and oleanic acids) that have anti-endema properties (Murray, 1995; Simons et al., 1998). In addition ferucil acid n-esters (e.g. n-docosanol and tetraconsanol) have been isolated from extracts that reduce prolactin levels and block the accumulation of cholesterol in the prostate (Murray 1995; Simons et al., 1998). Prolactin as well as cholesterol is involved in the AR-activating pathway, whereas prolactin increases the testosterone uptake in the prostate and cholesterol increases binding sites for DHT (Murray, 1995; Simons et al., 1998). 
Since the late 1960's bark extracts of Pygeum africanum are used in Europe to treat BPH (Isaacs, 1990). In France Pygeum africanum is the most commonly used medicine for BPH (Ishani et al., 2000; Levin and Das, 2000). Herby, the pulverized bark is incorporated into capsules and commercially available as the remedy $\operatorname{Tadenan}^{\circledR}$ and in other European countries under various different trade names (Ishani et al., 2000). In the USA phytotherapeutic agents like extracts of Pygeum africanum have been marketed for prostate health including PCa prevention and treatment (Shenouda et al., 2007).

Several studies have confirmed the positive effect of the extracts of Pygeum africaum on prostatic diseases (Breza et al, 1998; Cristoni et al., 2000; Katz, 2002; Gerber, 2002; Wilt et al., 2002; Buck 2004; Dedhia et al., 2008). Tadenan $^{\circledR}$ inhibited the proliferation of fibroblasts from human hyperplastic prostate and bladder (Edgar et al., 2007). Also, Tadenan $^{\circledR}$ has been shown to be a potent inhibitor of rat prostatic fibroblast proliferation in response to direct activators of protein kinase C. Moreover, the extract of Pygeum africaum is an inhibitor of a variety of growth factors including basic fibroblast growth factor, epidermal growth factor and insulin like growth factor (Yablonsky et al., 1997) and of G-protein coupled receptors (Solano et al., 2000). Other studies with male rats revealed that a co-treatment or a post-treatment of Tadenan ${ }^{\circledR}$ together with DHT suppressed the effects of DHT on micturition (Choo et al., 2000; Yoshimura et al., 2003). The co-treatment in addition decreased the prostatic weight (Yoshimura et al., 2003). In animal models extract of Pygeum africanum revealed to modulate bladder contractility by reducing the sensitivity of the bladder to electrical stimulation, phenylephrine, adenosine triphosphate and carbacol (Andro et al., 1995). Recently, the ethanolic extracts of Pygeum africanum were shown to inhibit human PCa cell growth, induce apoptosis and alter cell kinetics (Shenouda et al., 2007). TRAMP mice, a mouse model to investigate $\mathrm{PCa}$, exhibited a reduction of $\mathrm{PCa}$ incidence compared to the control group after feeding with Pygeum africanum extract (Shenouda et al., 2007).

In a single phase II study with patients having prostate hypertrophy a regression of the prostate size after $\operatorname{Tadenan}^{\circledR}$ administration was observed (Mathé et al., 1995). In clinical 
trials the application of Tadenan ${ }^{\circledR}$ has been shown to improve the symptoms of BPH and is well tolerated (Andro et al., 1995; Yablonsky et al., 1997; Chatelain et al., 1999). These results were confirmed by a multicentral trial in Europe, in which also nocturia was tested with the result that $32 \%$ of the male patients exhibited less symptoms (Breza et al., 1998). Even though all these effects of Pygeum africanum have been proven in vitro, in animal models and in clinical trials, the possibility for active antiandrogenic compounds to inhibit the AR remained elusive. Therefore, we investigated diverse extracts ( $n$-hexane, dichlormethane, methanol, methanol-water and water) from the stem bark of Pygeum africanum for their antiandrogenic potential using first reporter gene assays (Schleich et al., 2006b). The selective dichlormethane or ethanolic extract from Pygeum africanum bark material elicited the highest bioactivity. Hence, a bioassay-guided fractionation was performed resulting in the isolation of two novel antiandrogenic compounds with a novel chemical structure from Pygeum africanum: atraric acid (AA) and N-butylbenzenesulfonamide (NBBS) (Schleich et al., 2006a; 2006b).

\section{The natural compounds AA and NBBS}

The benzolic methylester AA is compared to steroids a very small molecule (Fig. 1). AA occurs in lichens and has been isolated from higher plants like Newbouldia laevis (Gormann et al., 2003), Alseodaphne andersonii (Lee et al., 2001), Acer nikense (Nagumo et al., 1996) and Frullania brasiliensis (Bardón et al., 2002). Previously it was found as a degradation product of various natural depsides. Even though AA is present in the extract of the bark from Pygeum africanum it is unknown whether it is a secondary metabolite of the plant biosynthesis itself or if it is produced by lichens colonizing the tree and producing polyketides through the acetate-polymalonate pathway. It is known that atranorin, a depside of hematommic acid, and AA are biosynthesized through the polyketide pathway by various lichens (Burgeois et al., 1999). 
NBBS was shown to be produced by the bacteria Pseudomonas sp. AB2 in greenhouse soil (Kim et al., 2000) and is like AA compared to steroids a small molecule (Fig. 1). Commonly NBBS is used as a plasticizer in the polyamide and co-polyamide production. It is also applied in the synthesis of sulfonyl carbamate herbicides. Because of its stability and persistance in the environment relatively high concentration have been found in wastewater and snow (concentrations up to $100 \mu \mathrm{g} / \mathrm{L}$ ) (Huppert et el. 1998, Poliakova et al., 2000). These findings reveal the possibility for NBBS to accumulate in organisms, but since we could isolate NBBS from several independent bark extracts and in Tadenan ${ }^{\circledR}$ it is likely that NBBS is present naturally in Pygeum africanum bark or could be produced by organisms living on the bark of the Pygeum africanum tree. Thus, even though NBBS can also be synthesized chemically it originates in nature.

Nevertheless, both compounds AA and NBBS are present in all investigated extracts of Pygeum africanum and therefore are more likely to be natural products.

According to WHO the P. africanum extracts are well tolerated in humans. Pre-studies with mice treated several times a week with AA did not indicate any side effects, assuming a good tolerance of AA (data not published). Concerning NBBS Even though it was found to be neurotoxic for rabbits (Strong et al., 1991) experiments with rats showed only slight effects at very high doses that were just of short duration (Kumar et al., 2007). In vitro studies revealed neuronal cells to be more sensitive in growth to NBBS treatment than glioma cells (Nerurkar et al., 1993) indicating different responses of cell types to NBBS.

In reporter gene assays a concentration of $10 \mu \mathrm{M}$ AA exhibited a repression of androgen ARmediated transactivation by about $90 \%$ (Schleich et al., 2006a). AA exhibits still $50 \%$ of inhibition at a concentration of $1 \mu \mathrm{M}$ and failed to repress the AR-mediated transactvation at $0.1 \mu \mathrm{M}$ (Schleich et al., 2006a). We synthesized ethyl, n-propyl and n-butyl derivatives of AA and found an even higher antiandrogenic activity of the ethyl and the n-propyl derivative, arguing that the length of the ester chain plays a crucial role in AR antagonism (Schleich et al., 2006a). 
Compared to AA, NBBS showed less efficacy on the androgen activated AR-mediated transactivation as $90 \%$ repression were obtained only with higher concentrations (100 $\mu \mathrm{M})$, a concentration of $10 \mu \mathrm{M}$ exhibited $50 \%$ repression and the antiandrogenic effect was lost at a dosage of $1 \mu \mathrm{M}$ of NBBS (Papaioannou et al., 2009b). A battery of NBBS derivatives was chemically synthesized to modify the butyl side chain and the benzene ring by substitutions with the aim of achieving more potent antiandrogens (Papaioannou et al., 2009b). Derivatives with a shortened butyl side chain or a substituted benzene ring at the paraposition caused a loss of the antiandrogenic potential. This strongly suggests the importance of the length of the side chain and an unsubstituted benzene ring at the para-position as antiandrogenic compound (Papaioannou et al., 2009b). Replacing the butyl side chain with a pentyl or a geranyl group in turn enhanced the antiandrogenic activity compared to NBBS, indicating that a hydrophobic side chain is important for AR antagonism but further extension weakened the effect (Papaioannou et al., 2009b). Notably, also substituents at the metaposition of the benzene ring enhanced the antiandrogenic activity.

In summary more potent derivatives of either AA or NBBS were synthesized. The antiandrogenic activity was mainly depending on the length of the alkyl side chain and in case of NBBS the position of the benzene substituents, revealing a crucial role of small changes in the structure of the natural compounds.

A marker for $\mathrm{PCa}$ is the serum level of the prostate specific antigen (PSA), an AR target gene. The endogenous PSA expression in the androgen-dependent human PCa cell line LNCaP harbouring an AR mutant, was significantly repressed by AA and NBBS (Papaioannou et al., 2009a; 2009b). Similar results were observed, performing real-time PCR with the androgen-independent growing PCa cell line C4-2, also containing the AR-T877A mutant.

To allow a specific targeted inhibition a very important characteristic of antiandrogens should be the AR specificity. The effect of both AA and NBBS was analyzed for the transcriptional properties of close related nuclear hormone receptors such as the progesterone receptor 
(PR), the glucocorticoid receptor (GR), the estrogen receptor $\alpha(E R)$ and $E R \beta$ as well as the thyroid hormone receptor $\beta$ (TR $\beta$ ). In case of PR both isoforms were tested, the PR-B form with a more potent transactivation function and the PR-A form, which is generated by an internal translation start site. For ER both the ERa and the ER $\beta$ were investigated. Neither AA nor NBBS had any measurable effect on the ligand-induced transactivation of GR, PR-A, $\mathrm{TR} \beta$, or one of the ER receptors in the concentrations used for $90 \%$ of $A R$ inhibition (Papaioannou et al., 2009a; 2009b). NBBS as well as AA showed an inhibitory effect at high concentrations for the PR-B form and AA additionally had estrogenic potential at high concentration of $100 \mu \mathrm{M}$ (Papaioannou et al., 2009a; 2009b). This slight repression and activation of other nuclear hormone receptors only at high employed concentrations suggest that $A A$ and NBBS are AR specific antiandrogens.

Eventually $\mathrm{PCa}$ becomes therapy resistant after a certain time of treatment with hormone ablation therapy. This therapy resistance may be due to several reasons one of which is due to AR mutations like the often occurring $A R$ point mutation T877A in castration resistant $\mathrm{PCa}$ (Culig et al., 1999). This point mutation in the ligand binding domain (LBD) of the AR renders the antiandrogenic metabolite $\mathrm{OH}-\mathrm{FI}$ of the recently used antihormone flutamide into an $\mathrm{AR}$ agonist. Notably, AA and NBBS exhibit repression of the AR-T877A mutant and therefore seem to have another molecular mechanism to mediate inhibition of AR compared to $\mathrm{OH}-\mathrm{FI}$ (Papaioannou et al., 2009a; 2009b).

One of the major goals in PCa therapy is the growth inhibition of the cancer cells. AA and NBBS decreased the cell proliferation of several human prostate cancer cell lines either growing androgen dependently and containing the wild type AR or the AR-T877A mutant or growing androgen independently and containing the AR-T877A mutant (C4-2). In contrast, growth of PC3 cells lacking expression of the AR or non PCa cells also lacking AR expression were not effected by $A A$ and NBBS, suggesting an AR-dependent growth inhibitory mechanism imposed by AA and NBBS (Papaioannou et al., 2009a; 2009b). Also, neither toxicity nor apoptosis could be observed during the treatment. 
The synthetic AR agonist R1881 promotes beside PCa cell proliferation also the invasion through the extracellular matrix, in consequence invasion of cells, an important step for PCa metastasis (Chuan et al., 2006). In line with this AA inhibited the androgen-induced invasion of human LNCaP cells (Papaioannou et al., 2009a) while AA alone had no influence on the cell invasion. Thus, AA inhibits the agonist-induced invasion of LNCaP cells through the extracellular matrix and therefore could be a potential inhibitor also for PCa metastasis.

\section{Insights in the molecular mechanism of AA and NBBS}

To identify the important AR sites for the inhibitory mechanism of AA and NBBS on ARmediated transactivation several AR deletion mutants were analyzed. The results suggest that the AR-LBD is targeted by AA and NBBS, indicating binding of the compounds to the AR-LBD that may lead to competition with androgen binding (Papaioannou et al., 2009a; 2009b). This hypothesis was verified by whole cell competition binding analysis with AR agonists confirming the release of androgens by either AA and NBBS indicating that both compounds act as competitive inhibitors (Papaioannou et al., 2009a; 2009b).

One possible mechanism to inhibit AR could be to reduce its protein level such as by enhanced protein degradation. However, treatment of PCa cells with AA or NBBS did not reveal a decrease of the AR protein suggesting that $A A$ and NBBS do not induce $A R$ degradation and suggesting that AA and NBBS use other mechanisms to inhibit the AR. Another hypothesis was that AA or NBBS might induce CoR binding to AR. However, testing the interaction of three CoR such as SMRT, NCoR and Alien did not indicate a binding of these CoR to either AA or NBBS bound AR.

A further possibility for NBBS and AA to inhibit AR-mediated transactivation would be the inhibition of the translocation of AR into the nucleus. Using GFP-AR as expected the staining was cytoplasmatic without androgens whereas the majority of staining was observed in the nucleus with androgen treatment of cells. Interestingly, the androgen-induced translocation of AR was inhibited by a co-treatment with AA or NBBS. These results were confirmed by cell 
fractionation experiments. Thus, the data suggest that both compounds inhibit the androgen induced AR translocation into the nucleus (Papaioannou et al., 2009a; 2009b). In contrast to casodex also recently published diarylthiohydantions with antiandrogenic activity such as AA and NBBS do not themselves translocate the AR into the nucleus (Tran et al., 2009). However, it was not investigated whether this diarylthiohydantions also inhibit the nuclear translocation of the AR in the presence of androgens.

Taken together, two compounds from the bark of Pygeum africanum were isolated that exhibit a novel molecular mechanism to repress the AR-mediated transactivation by inhibiting its nuclear translocation.

\section{Discussion}

With AA and NBBS, to our knowledge the first natural AR antagonists were isolated and identified from Pygeum africanum, from which plant extracts are used for a long time in the treatment of prostatic diseases.

DHT as well as the synthetic androgen R1881 are very hydrophobic molecules and are thought to not require an active process to pass the cell membrane (Fedoruk et al., 2004). AA and NBBS are more hydrophilic and therefore the mode of cellular uptake may not be comparable, as the lipophilic cell membrane is a barrier for those molecules. Hence, the used concentrations for cell treatment do not necessarily reflect the intracellular concentrations of both compounds, so the concentrations may be lower than those added in the experiments. In addition it was shown for other natural compounds that they require a similar concentration range of action (Zi et al., 1999; 2000; Xing et al., 2001; Kiviharju et al., 2002; Rosenberg Zand et al., 2002; Thelen et al., 2004). It is also possible that AA and NBBS may act together with other compounds and therefore potentiating the overall effect on prostatic diseases. For instance extracts form Pygeum africanum were shown to inhibit membrane receptors that are involved in AR signaling and thus suppress AR activity (Yablonski et al., 1997; Szolnoki et 
al., 2001; Santa Maria Margalef et al., 2003; Boulbès et al., 2006; Edgar et al., 2007; Li et al., 2007; Quiles et al., 2010) (Fig. 2).

The molecular mechanisms of currently clinically used antiandrogens for PCa treatment is based on the recruitment of co-repressors or through changing chromatin accessibility (Dotzlaw et al., 2002; Shang et al., 2002; Kang et al., 2004; Hodgson et al., 2005; Hong et al., 2005; Metzger et al., 2005). These antiandrogens permit AR translocation into the nucleus as well as the recruitment of the AR with CoR to its target genes (Jenster et al., 1993; Masiello et al., 2002; Zhu et al., 2006). One basis of resistance of PCa to the hormone therapy may be due to malfunctioning of AR inhibition by these CoR. Therefore, the different CoR-independent molecular mechanism of AA and NBBS to inhibit the AR nuclear translocation may be a useful tool for hormone treatment of those refractory PCa (Fig. 3).

Comparing the $\mathrm{IC}_{50}$ of $\mathrm{AA}(3 \mu \mathrm{M})$ and NBBS $(10 \mu \mathrm{M})$ with that of casodex $(1 \mu \mathrm{M})$ (Hadratta et al., 2005) both compounds exhibit only slightly weaker efficiencies. In comparison with the clinically used antiandrogen flutamide $\left(\mathrm{IC}_{50}\right.$ of $\left.116 \mu \mathrm{M}\right)$ (Hadratta et al., 2005) AA and NBBS are even more potent. Thus, assuming that this natural compounds could be quite potent PCa inhibitors in vivo.

Furthermore, we synthesized more potent AA and NBBS derivatives with the same underlying molecular mechanism for the analyzed NBBS derivatives. The enhanced antiandrogenic potential of this derivatives may be due to their higher lipophilicity compared to AA and NBBS respectively, but structural modifications seem also to play a role as also more lipophilic derivatives of AA and NBBS were synthesized that showed less or even no anitandrogenic potential (Papaioannou et al., 2009b and data not published). Additional substitutions at the benzolic ring of NBBS also resulted in some cases in an increased inhibition of AR-mediated transactivation (Papaioannou et al., 2009b). Thus, NBBS and AA may serve as novel chemical platform molecules to inhibit the AR transactivation and PCa growth and may serve as lead structures for new AR antagonists. 


\section{Acknowledgement}

This work was supported by the Deutsche Krebshilfe to A.B.

\section{References}

Andro, M.C., Riffaud, J.P., 1995. Pygeum africanum extract for the treatment of patients with benign prostatic hyperplasia: a review of 25 years of published experience. Curr. Ther. Res. 56: 796-817.

Balk, S.P., 2002. Androgen receptor as a target in androgen-independent prostate cancer. Urology 60(3 Suppl 1):132-8.

Baniahmad, A., 2005. Nuclear hormone receptor co-repressors. J. Steroid. Biochem. Mol. Biol. 93(2-5): 89-97.

Bardón, A., Bovi, Mitre, G., Kamiya, N., Toyota, M., Asakawa, Y., 2002 Eremophilanolides and other constituents from the argentine liverwort Frullania brasiliensis. Phytochemistry 59: 205-13.

Breza, J., Dzurny, O., Borowka, A., Hanus, T., Petrik, R., Blane, G., Chadha-Boreham, H., 1998. Efficacy and acceptability of tadenan (Pygeum africanum extract) in the treatment of benign prostatic hyperplasia (BPH): a multicentre trial in central Europe. Curr. Med. Res. Opin. 14: 127-39.

Brinkmann, A.O., Blok, L.J., de Ruiter, P.E., Doeseburg, P., Steketee, K., Berrevoets, C.A., Trapman, J. 1999. Mechanisms of androgen receptor activation and function. J. Steroid. Biochem. Mo.I Biol. 69: 307-13.

Brinkmann, A.O., and Trapman J., 2000. Prostate cancer schemes for androgen escape. Nat. Med. 6:628-629.

Boulbès, D., Soustelle, L., Costa, P., Haddoum, M., Bali, J.P., Hollande, F., Magous, R., 2006. Pygeum africanum extract inhibits proliferation of human cultured prostatic fibroblasts and myofibroblasts. BJU Int. 98(5): 1106-13. 
Bombardelli, E., Morazzoni, P., 1997. Prunus Africana. Fitoterapia 68: 205-18.

Buck, A.C., 2004. Is there a scientific basis for the therapeutic effects of serenoa repens in benign prostatic hyperplasia? Mechanisms of action. J Urol. 172(5): 1792-9.

Burgeois, G., Suire, C., Vivas, N., 1999. Atraric acid, a marker for epiphytic lichens in the wood used in cooperage : identifiaction and quantification by $\mathrm{GC} / \mathrm{MS} /(\mathrm{MS})$. Analysis 27 : 281-3.

Burke, L.J. and Baniahmad, A., 2000. Co-repressors. FASEB J 14: 1876-88.

Cato, A.C., Nestl, A., Mink, S., 2002. Rapid actions of steroid receptors in cellular signaling pathways. Sci. STKE, 138:re9.

Chatelain, C., Autet, W., Brackman, F., 1999. Comparison of once and twice daily dosage forms of Pygeum africanum extract in patients with benign prostatic hyperplasia: a randomized, double-blind study, with long term open label extension. Urology 54: 473-8.

Chen, C.D., Welsbie, D.S., Tran, C., Baek, S.H., Chen, R., Vessella, R., Rosenfeld, M.G., Sawyers, C.L., 2004. Molecular determinants of resistance to antiandrogen therapy. Nat. Med. 10(1):33-9.

Choo, M.S., Bellamy, F., Constantinou, C.E., 2000. Functional evaluation of Tadenan on micturition and experimental prostate growth induced with exogenous dihydrotestosterone . Urology 55(2): 292-8.

Chuan, Y.C., Pang, S.T., Cedazo-Minguez, A., Norstedt, G., Pousette, A., Flores-Morales, A., 2006. Androgen induction of prostate cancer cell invasion is mediated by ezrin. J. Biol. Chem. 281: 29938-48.

Cristoni, A., Di Pierro, F., Bombardelli, E., 2000. Botanical derivatives for the prostate. Fitoterapia 71 Suppl1: S1-8.

Culig, Z., Hoffmann, J., Erdel, M., Hobisch, A., Hittmair, A., Bartsch, G., Utermann, G., Schneider, M.R., Parczyk, K., Klocker, H., 1999. Swith from antagonist to agonist of the androgen receptor bicalutamide is associated with prostate tumor progression in a new model system. Br. J. Cancer 81: 242-51. 
Denmeade SR, Isaacs JT 2001 A history of prostate cancer treatment. Nat Rev Cancer 2:389-96.

Dhedia, R.C., Calhoun, E., McVary, K.T., 2008. Impact of phytotherapy on utility scores for 5 benign prostatic hyperplasia/lower urinary tract symptoms health states. J Urol. 179(1): 220-5.

Dotzlaw, H., Moehren, U., Mink, S., Cato, A.C., Iniguez Luhi, J.A., Baniahmad, A., 2002. The amino terminus of the human AR is target for corepressor action and antihormone agonism. Mol. Endocrinol. 16:661-673.

Dotzlaw, H., Papaioannou, M., Moehren, U., Claessens, F., Baniahmad, A., 2003. Agonistantagonist induced coactivator and corepressor interplay on the human androgen receptor. Mol. Cell. Endocrinol. 213(1):79-85.

Dreikorn, K., 2002. The role of phytotherapy in treating lower urinary tract symptoms and benign prostatic hyperplasia. World. J. Urol. 19: 426-35.

Edgar, A.D., Levin, R., Constantinou, C.E., Denis, L. 2007. A critical review of the pharmacology of the plant extract of Pygeum africanum in the treatment of LUTS. Neurourol. Urodyn. 26: 458-463.

Edwards, B.K., Ward, E., Kohler, B.A., Eheman, C., Zauber, A.G., Anderson, R.N., Jemal, A., Schymura, M.J., Lansdorp-Vogelaar, I., Seeff, L.C., van Ballegooijen, M., Goede, S.L., Ries, L.A.G., 2010. Annual Report to the Nation on the Status of Cancer, 1975-2006, Featuring Colorectal Cancer Trends and Impact of Interventions (Risk Factors, Screening, and Treatment) to Reduce Future Rates. Cancer 116: 544-73.

Eisold M., Asim, M., Eskelinen, H., Linke, T., Baniahmad, A., 2009. Inhibition of MAPKsignaling pathway promotes the interaction of the corepressor SMRT with the human androgen receptor and mediates repression of prostate cancer cells growth in the presence of antiandrogens. J. Mol. Endocrinol. 42: 429-35.

Farla P, Hersmus R, Trapman J, Houtsmuller AB 2005 Antiandrogens prevent stable DNAbinding of the androgen receptor. J Cell Sci 118: 4187-4198 
Fedoruk, M.N., Gimenez-Bonafe, P., Guns, E.S., Mayer, L.D., Nelson, C.C., 2004. Pglycoprotein increases the efflux of the androgen dihydrotestosterone and reduces androgen responsive gene activity in prostate tumor sells. Prostate 59: 77-90.

Feldman, B.J., and Feldman, D., 2001. The development of androgen-independent prostate cancer. Nat. Rev. Cancer. 1:34-45.

Fuhrman, U., Parczynk, K., Klotzbucher, M., Klocker, H., Cato, A.C., 1998. Recent developments in molecular action of antihormones. J. Mol Med 76, 512-524.

Gerber, G.S., 2002. Phytotherapy for benign prostatic hyperplasia. Curr. Urol. Rep. 3(4): 28591.

Gormann, R., Kaloga, M., Li, X.C., Ferreira, D., Bergenthal, D., Kolodziej, H., 2003. Furanonaphthoquinones, atraric acid and a benzofuran from the sterm barks of Newbouldia laevis. Phytochemistry 64: 583-7.

Handratta, V.D., Vasaitis, T.S., Njar, V.C.O., Gediya, L.K., Kataria, R., Chopra, P., Newman, D.Jr., Farquhar, R., Guo, Z., Qui, Y., Brodie, A.M.H., 2005. Novel C-17 heteroaryl steroidal CYP17 inhibitors/antiandrogens: synthesis, in vitro biological activity, pharmacokinetics, and antitumor activity in the LAPC4 human prostate cancer xenograft model. J. Med. Chem. 48, 2972-2984.

Hodgson, M.C., Astapova, I., Cheng, S., Lee, L.J., Verhoeven, M.C., Choi, E., Balk, S.P., Hollenberg, A.N., 2005. The androgen receptor recruits nuclear receptor CoRepressor $(\mathrm{N}-\mathrm{CoR})$ in the presence of mifepristone via its $\mathrm{N}$ and $\mathrm{C}$ termini revealing a novel molecular mechanism for androgen receptor antagonists. J. Biol. Chem. 280(8):6511-9.

Hong, C.Y., Gong, E.Y., Kim, K., Suh, J.H., Ko, H.M., Lee, H.J., Choi, H.S., Lee, K., 2005. Modulation of the expression and transactivation of androgen receptor by the basic helixloop-helix transcription factor Pod-1 through recruitment of histone deacetylase 1 . Mol. Endocrinol. 19(9):2245-57. 
Huppert, N., Würtele, M., Hahn, H.H., 1998. Determination of the plasticizer Nbutylbenezensulfonamide and the pharmaceutical Ibuprofen in wastewater using solid phase microextraction (SPME). Fresenius. J. Anal. Chem. 362: 529-36.

Isaacs, J.T., 1990. Importance of the natural history of benign prostatic hyperplasia in the evaluation of pharmacologic intervention. Prostate 3: 1-7.

Ishani, A., MacDonald, R., Nelson, D., Rutks, I., Wilt, T.J., 2000. Pygeum africanum for the treatment of patients with benign prostatic hyperplasia: a systematic review and quantitative meta-analysis. Am. J. Med. 109: 654-664.

Jemal, A., Siegel, R., Ward, E., Hao, Y., Xu, J., Murray, T., Thun, M.J., 2008. Cancer Statistics. CA. Cancer. J. Clin. 58:71-96.

Jenster, G., Trapman, J., Brinkmann, A.O., 1993. Nuclear import of the human androgen receptor. Biochem. J. 293: 761-8.

Kang, Z., Jänne, O.A., Palvimo, J.J., 2004. Coregulator recruitment and histone modifications in transcriptional regulation by the androgen receptor. Mol. Endocrinol.18(11):2633-48.

Katz, A.E., 2002. Flavonoid and botanical approaches to prostate health. J Altern. Complement. Med. 8(6): 813-21.

Kim, K.K., Kang, J.G., Moon, S., Kang, KY., 2000. Isolation and identification of antifungal Nbutylbenzenesulfonamide produces by Pseudomonas sp AB2. J. Antibiot. 53: 131-6.

Kumar, G., Smith, Q.R., Hokari, M., Parepally, J., Duncan, M.W., 2007. Brain uptake, pharmacokinetics, and tissue distribution in the rat of neurotoxic $\mathrm{N}$ butylbenzenesulfonamide. Toxicol Sci. 97(2), 253-264.

Kiviharju, T.M., Lecane, P.S., Sellers, R.G., Peehl, D.M., 2002. Antiproliferative and proapoptotic activities of triptolide (PG490), a natural product entering clinical trials, on primary cultures of human prostatic epithelial cells. Clin. Cancer. Res. 8:2666-74.

Labrie, C., Simard, J., Zhao, H.F., Belanger, A., Pelletier, G., Labrie, F., 1989. Stimulation of androgen -dependent gene expression by the adrenal precursors dehydroepi- 
androsterone and androstenedione in the rat ventral prostate. Endocrinology 124, 27452754.

Lee, S.S., Chang, S.M., Chen, C.H., 2001. Chemical constituents from Alseodaphne andersonii. J Nat. Prod. 64: 1548-51.

Levin, R.M. and Das, A.K., 2000. A scientific basis for the therapeutic effects of Pygeum africanum and Serenoa repens. Urol. Res. 28(3): 201-9.

Li, Y., Shi, B., Wang, D., Wang, P., Laudon, V., Zhang, J., Liu, Y., 2007. Nerve growth factor and substance P: expression in a rat model of diabetic bladder. Int. Urol. Nephrol. (in press).

Mathé, G., Hallard, M., Bourut, C.H., Chenu, E., 1995. A pygeum africanum extract with so-called phyto-estrogenic action markedly reduces the volume of true and large prostatic hypertrophy. Biomed. Pharmacother. 49(7-8): 341-3.

Marcelli, M., Stenoien, D.L., Szafran, A.T., Simeoni, S., Agoulnik, I.U., Weigel, N.L., Moran, T., Mikic, I., Price, J.H., Mancini, M.A., 2006. Quantifying Effects of Ligands on Androgen ReceptorNuclear Translocation, Intranuclear Dynamics, and Solubility. J. Cell. Biochem. 98:770-788.

Masiello, D., Cheng, S., Bubley, G.J., Lu, ML., Balk, S.P., 2002. Bicalutamide functions as an androgen receptor antagonist by assembly of a transcriptionally inactive receptor. J. Biol. Chem. 277: 26321-6.

Metzger, E., Wissmann, M., Yin, N., Muller, J.M., Schneider, R., Peters, A.H., Gunther, T., Buettner, R., Schuele, R., 2005. LSD1 demethylates repressive histone marks to promote androgen-receptor-dependent transcription. Nature 437(7057):436-9.

Murray, M.T., 1995. The healing power of herbs. Pockiln, CA: Prima Publishing 286-293.

Migliari, R., Muscas, G., Murru, M., Verdacchi, T., De Benedetto, G., De Angelis, M., 1999. Antiandrogens: a summary review of pharmacodynamic properties and tolerability in prostate cancer therapy. Arch, Ital, Urol, Androl. 71(5): 293-302. 
Nagumo, S., Ishizawa, S., Nagai, M., Inoue, T., 1996. Studies on the conctituents of Aceraceae plants. XIII. Diarylheptanoids and other phenolics from Acer nikoense. Chem. Pharm .Bull. 44: 1086-9.

Nakauchi, H., Matsuda, K., Ochiai, I., Kawauchi, A., Mizutani, Y., Miki, T., Kawata, M. 2007. A Differential Ligand-mediated Response of Green Fluorescent Protein-tagged Androgen Receptor in Living Prostate Cancer and Non-prostate Cancer Cell Lines, J. Histochem. Cytochem. 55(6): 535-544.

Nerurkar, V.R., Wakayama, I., Rowe, T., Yanagihara, R., Garruto, R.M., 1993. Preliminary observations on the in vitro toxicity of $\mathrm{N}$-butylbenzenesulfonmide: a newly discovered neurotoxic. Ann N Y Acad Sci. 28: 679, 280-7.

Ntais, C., Polycarpou, A., Tsatsoulis, A., 2003. Molecular epidemiology of prostate cancer: androgens and polymorphisms in androgen-related genes. Eur. J. Endocrinol. 149:469-77.

Papaioannou, M., Reeb, C., Asim, M., Dotzlaw, H., Baniahmad, A., 2005. Co-activator and co-repressor interplay on the human androgen receptor. Andrologia 37: 211-212.

Papaioannou, M., Schleich, S., Prade, I., Degen, S., Roell, D., Schubert, U., Tanner, T., Claessens, F., Matusch, R., Baniahmad, A., 2009a. The natural compound atraric acid is an antagonist of the human androgen receptor inhibiting cellular invasiveness and prostate cancer cell growth. J. Cell. Mol. Med. 13: 2210-2223.

Papaioannou, M., Schleich, S., Roell, D., Schubert, U., Tanner, T., Claessens, F., Matusch, R., Baniahmad, A., 2009b. NBBS isolated from Pygeum africanum bark exhibits androgen antagonistic activity, inhibits AR nuclear translocation and prostate cancer cell growth. Invest. New. Drugs. (in press).

Poliakove, O.V., Lebedev, A.T., Hänninen, O., 2000. Organic pollutants in snow of urban and rural Russia and Finland. Ebvorin. Toxicol. Chem. 75: 181-94.

Powell, S.M., Brooke, G.N., Whitaker, H.C., Reebye, V., Gamble, S.C., Chotai, D., Dart, D.A., Belandia, B., Bevan, C.L., 2006. Mechanisms of androgen receptor repression in prostate cancer. Biochem. Soc. Trans. 34(Pt 6):1124-7. 
Quiles, M.T., Arbós, M.A., Fraga, A., de Torres, I,M., Reventós, J., Morote, J., 2010. Antiproliferative and apoptotic effects of the herbal agent Pygeum africanum on cultured prostate stromal cells from patients with benign prostatic hyperplasia (BPH). Prostate 70(10):1044-53

Rosenberg Zand, R.S., Jenkins, D.J., Brown, T,J., Diamandis, E.P., 2002. Flavonoids can block PSA production by breast and prostate cancer cell lines. Clin. Chim. Acta. 317:1726.

Santa María Margalef, A., Paciucci Barzanti, R., Reventós Puigjaner, J., Morote Robles, J., Thomson Okatsu T,M., 2003. Antimitogenic effect of Pygeum africanum extracts on human prostatic cancer cell lines and explants from benign prostatic hyperplasia. Arch. Esp. Urol. 56(4): 369-78.

Schleich, S., Papaioannou., M., Baniahmad, A., Matusch, R., 2006a. Activity-guided isolation of an antiandrogenic compound of Pygeum afcricanum. Planta. Med. 72: 547-51.

Schleich., S., Papaioannou., M., Baniahmad., A., Matusch, R., 2006b. Extracts from Pygeum africanum and other ethnobacterial species with antiandrogenic activity. Planta. Med. 72: 807-813.

Shah, U.S., Getzenberg, R.H., 2004. Fingerprinting the diseased prostate, associations between BPH and prostate cancer. J. Cell. Biochem. 91:161-9.

Shang, Y., Myers, M., Brown, M., 2002. Formation of the androgen receptor transcription complex. Mol. Cell. 9:601-10.

Shenouda, N.S., Sakla, M.S., Newton, L.G., Besch-Williford, C., Greenberg, N.M., MacDonald, R.S., Lubahn, D.B., 2007. Phytosterol Pygeum africanum regulates prostate cancer in vitro and in vivo. Endocrine. $31:$ 72-81.

Simons, A.J., Dawson, I.K., Dugumba, B., Tchoundjeu, Z., 1998. Passing problems: prostate and prunus. Herbal. Gram. 43: 49-53.

Skolarikos, A., Thorpe, A.C., Neal, D.E., 2004. Lower urinary tract symptoms and benign prostatic hyperplasia. Minerva. Urol. Nefrol. 56: 109-22. 
Solano, R.S., García-Fernandéz, M.O., Clemente, C., Querol, M., Bellamy, F., SanchezChapado, M., Prieto, J.C., Carmena, M.J., 2000. Effects of pygeum africanum extract $\left(\right.$ Tadenan $\left.^{\circledR}\right)$ on vasoactive intestinal peptide receptors, G proteins, and adenylyl cyclase in rat ventral prostate. Prostate 45: 245-252.

Song, L.N., Coghlan, M., Gelmann, E.D.P., 2004. Antiandrogen Effects of Mifepristone on Coactivator and Corepressor Interactions with the Androgen Receptor. Mol. Endocrinol. 18(1):70-85.

Strong, M.J., Garruto, R.M., Wolff, A.V., Chou, S.M., Fox, S.D., Yanagihara, R., 1991. Nbutylbenzenesulfonamide: a neurotoxic plasticizer inducing a spastic myelopathy in rabbits. Acta Neuropathol 81, 235-241.

Szolnoki, E., Reichart, E., Marchal, S., Szegedi, G., 2001. The effect of Pygeum africanum on fibroblast growth factor (FGF) and transforming growth factor beta (TGF beta 1/LAP) expression in animal model. Acta. Microbiol. Immunol. Hung. 48(1): 1-9.

Tenbaum., S. and Baniahmad, A., 1997. Nuclear receptors: structure, function and involvement in disease. Int. J. Biochem. Cell. Biol. 29: 1325-41.

Thelen, P., Jarry, H., Ringert, R.H., Wuttke, W., 2004. Silibinin downregulates prostate epithelium-derived Ets transcription factor in LNCaP prostate cancer cells. Planta. Med. 70:397-400.

Tran, C., Ouk, S., Clegg, N.J., Watson, P.A., Arora, V., Wongvipat, J., Smith-Jones, P.M., Yoo, D., Kwon, A., Wasielewska, T., Welsbie, D., Chen, C.D., Higano, C.S., Beer, T.M., Hung, D.T., Scher, H.I., Jung, M.E., Sawyer, C.L., 2009. Development of a secondgeneration antiandrogen for treatment of advanced prostate cancer. Science 324, 787790.

Tyagi, K.R., Lavrovsky, Y., Ahn, S.C., Song, C.S., Chatterjee, B., Roy, A.K., 2000. Dynamics of IntracellularMovement and Nucleocytoplasmic Recycling of the Ligand-Activated Androgen Receptor in Living Cells. Mol. Endocroinol. 14(8): 1162-1174. 
Vis, A.N. and Schröder, F.H., 2009. Key target of hormonal treatment of prostate cancer. part 2: the androgen receptor and 5 $\alpha$-reductase. BJUI 104(9):1191-7.

Wang, L., Hsu, C.L., Chang, C., 2005. Androgen receptor corepressors: an overview. Prostate 63(2):117-30.

Wilt, T., Ishani, A., Mac Donald, R., Rutks, I., Stark, G., 2002. Pygeum africanum for benign prostate hyperplasia. Cochrane Database Syst. Rev. 1: CD001044.

Xing, N., Chen, Y., Mitchell, S.H., Young, C.Y., 2001. Quercetin inhibits the expression and function of the androgen receptor in LNCaP prostate cancer cells. Carcinogenesis. 22:409-14.

Yablonsky, F., Nicolas, V., Riffaud, J.P., Bellamy, F., 1997. Antiproliferative effect of Pygeum africanum extract on rat prostatic firbroblasts. J. Urol. 157: 2381-7.

Yoshimura, Y., Yamaguchi, O., Bellamy, F., Constantinou, C.E., 2003. Effect of Pygeum africanum Tadenan on micturition and prostate growth of the rat secondary to coadministered treatment and post-treatment with dihydrotestosterone. Urology 61: 474478.

Zi, X., Agarwal, R., 1999. Silibinin decreases prostate-specific antigen with cell growth inhibition via G1 arrest, leading to differentiation of prostate carcinoma cells: implications for prostate cancer intervention. Proc. Natl. Acad. Sci. U S A 96:7490-5.

Zi, X., Zhang, J., Agarwal, R., Pollak, M., 2000. Silibinin up-regulates insulin-like growth factor-binding protein 3 expression and inhibits proliferation of androgen-independent prostate cancer cells. Cancer. Res. 60:5617-20.

Zhu, P., Baek, S.H., Bourk, E.M., 2006. Macrophage/cancer cell interactions mediate hormone resistance by a nuclear receptor derepression pathway. Cell. 124: 615-29. 


\section{Figure Legends}

Fig 1. Molecular structure of the natural antiandrogenic compounds atraric acid (AA), Nbutylbenzene-sulfonamide (NBBS) and exemplary derivatives thereof compared to the androgen dihydrotestosterone (DHT).

AA is benzolic methylester with two additional methyl groups on C-atoms at positions 3 and

6. As subtituents on position 2 and 4 the benzol ring carries hydroxyl groups. The n-propyl derivative is elongated at the alkyl side chain. The scaffold of NBBS is also a benzol ring, whereas the substituent is a sulfone amide group followed by a butyl chain. The indicated NBBS derivative carries an additional tri-fluride group at the meta position of the benzol ring and the amide an additional hydrogen. All four molecules are smaller compared to steroids such as the androgen DHT. Further derivatives of AA and NBBS have other changed side chains or substituents (see text for details).

Fig 2. Inhibition pathways of the AR by extract of Pygeum africanum.

Compounds of Pygeum africanum extract inhibit the activity of several membrane receptors and through down stream signaling might also repress the AR. Further, the compounds of Pygeum africanum AA and NBBS inhibit the nuclear translocation, leading to AR suppression.

Fig 3. Molecular mechanisms of AR-inhibition by antagonists.

A) Currently used AR antagonists (e.g. casodex) bind to the AR, induce a conformational change that leads to the dissociation of the AR bound heat shock proteins (Hsp), then to the translocation into the nucleus and homodimerisation. In the nucleus the antagonist-bound AR, recruits corepressors and hereby its transcriptional activity is repressed.

B) $A A$ as well as NBBS bind to the $A R$ and inhibit the nuclear translocation and in consequence its function as an androgen-activated transcription factor. 


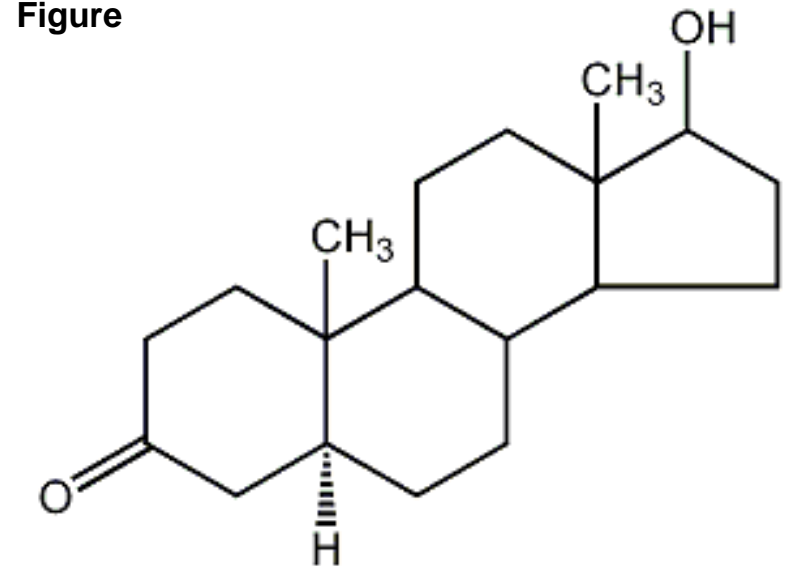

Dihydrotestosterone (DHT)

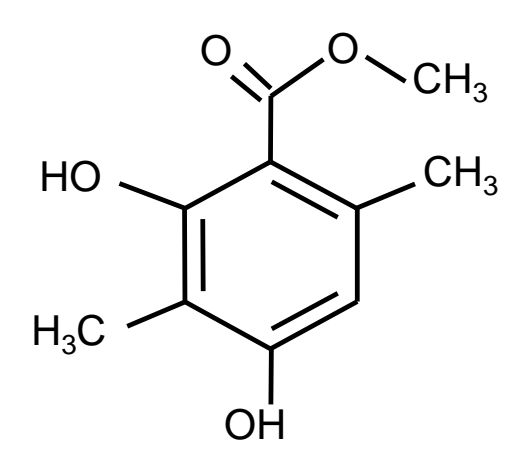

Atraric Acid

(AA)

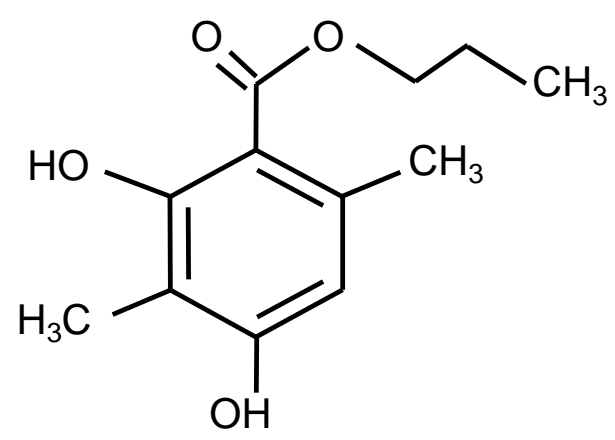

n-propyl 2,4-dihydroxy3,6-dimethylbenzoate (AA derivative)

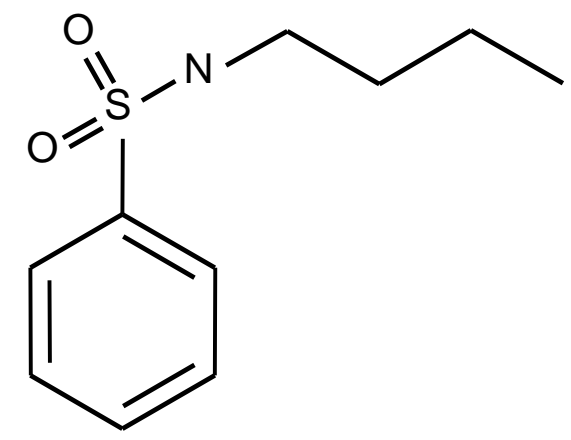

$\mathrm{N}$-butylbenzene-sulfonamide (NBBS)

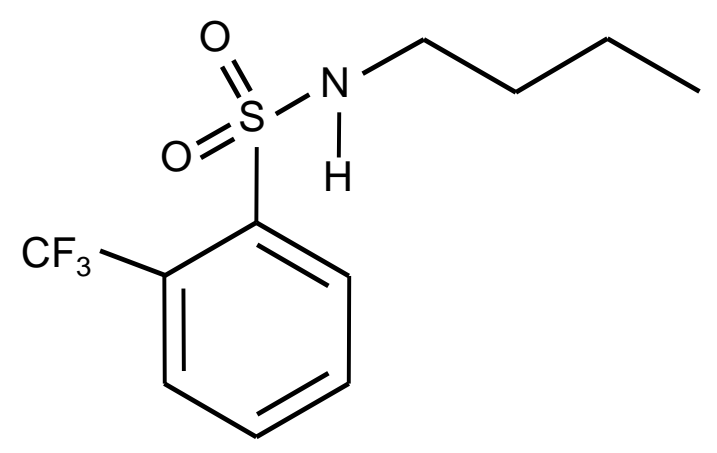

n-butyl 3-trifluoromethylbenzene-sulfonamide (NBBS derivative) 


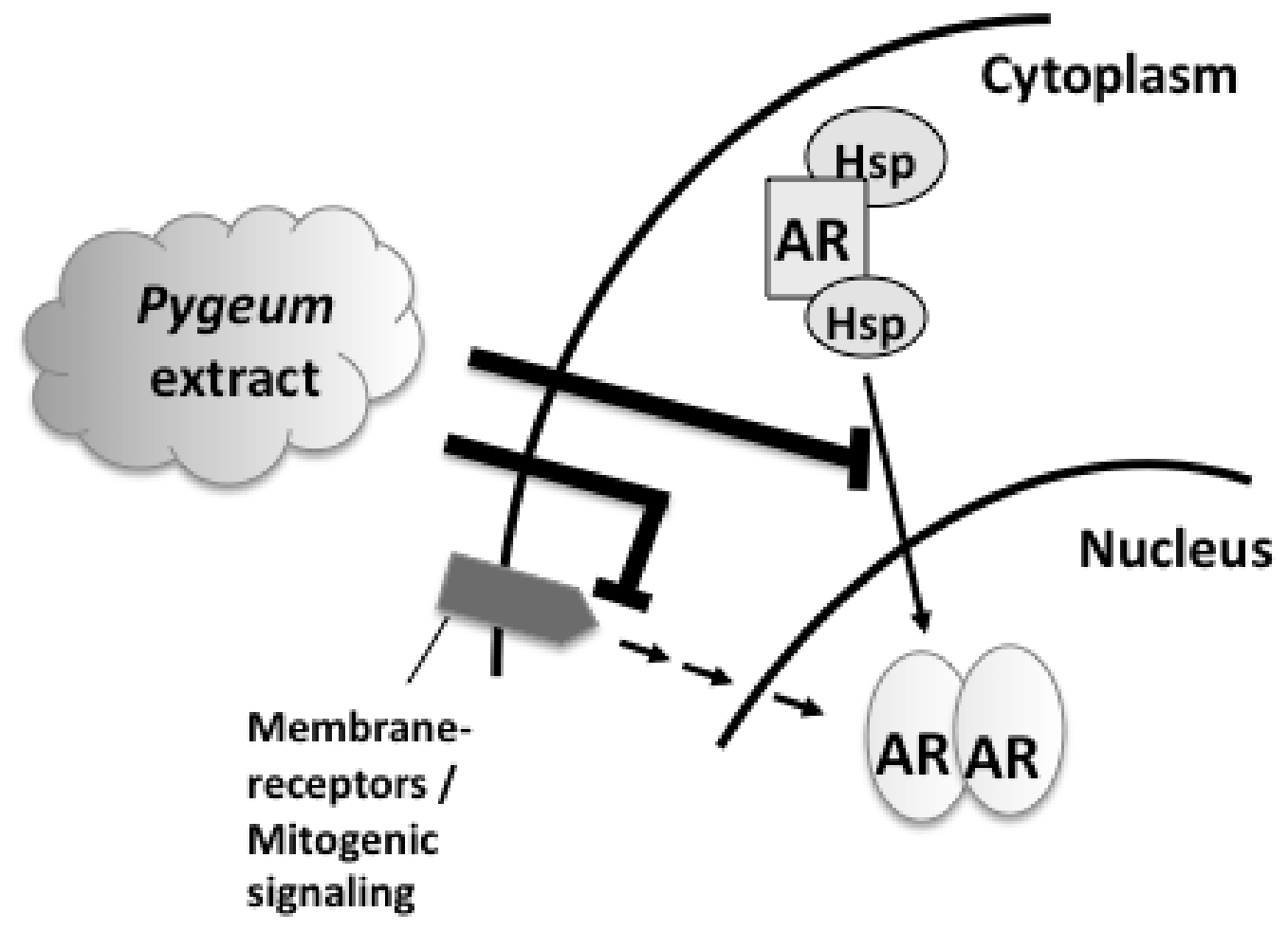

Fig. 2 
A

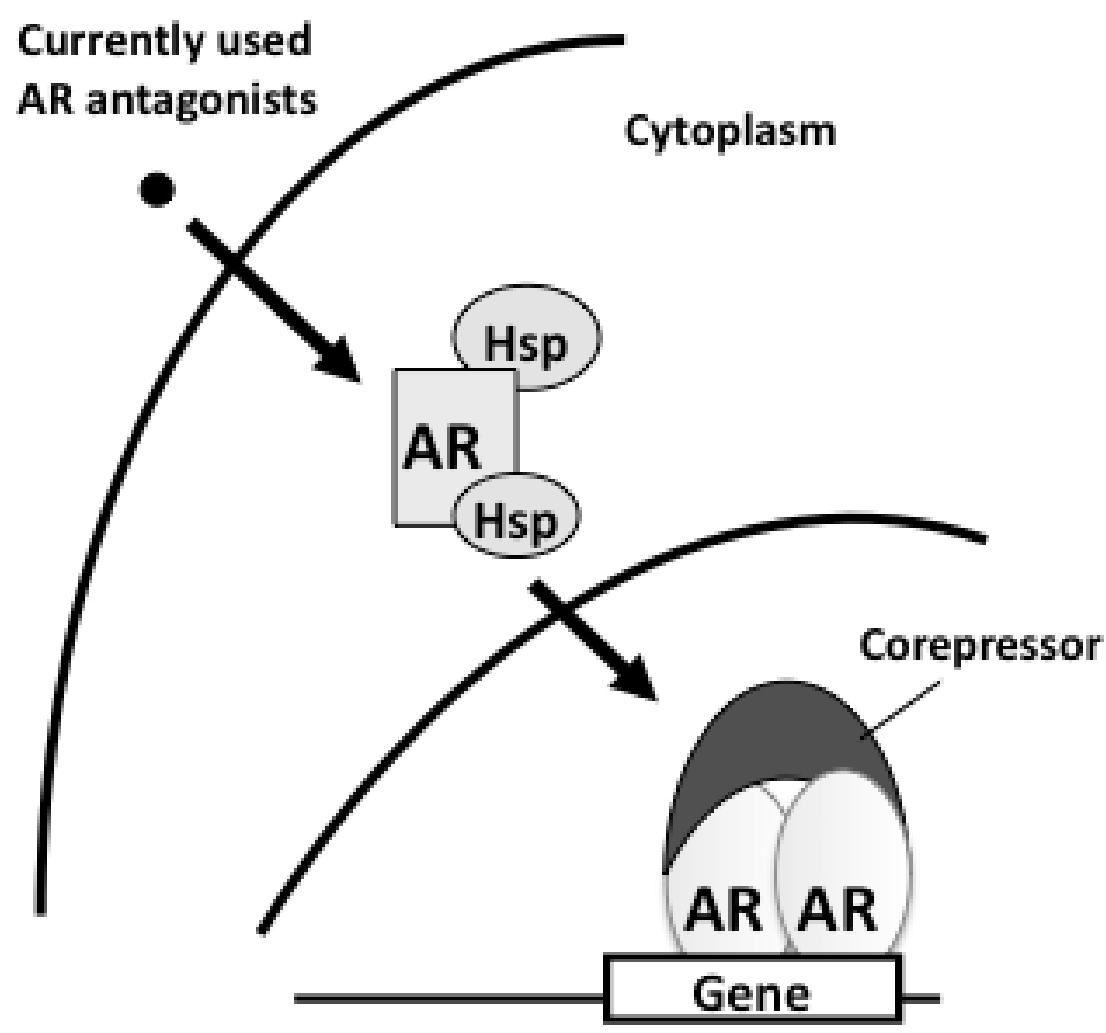

B

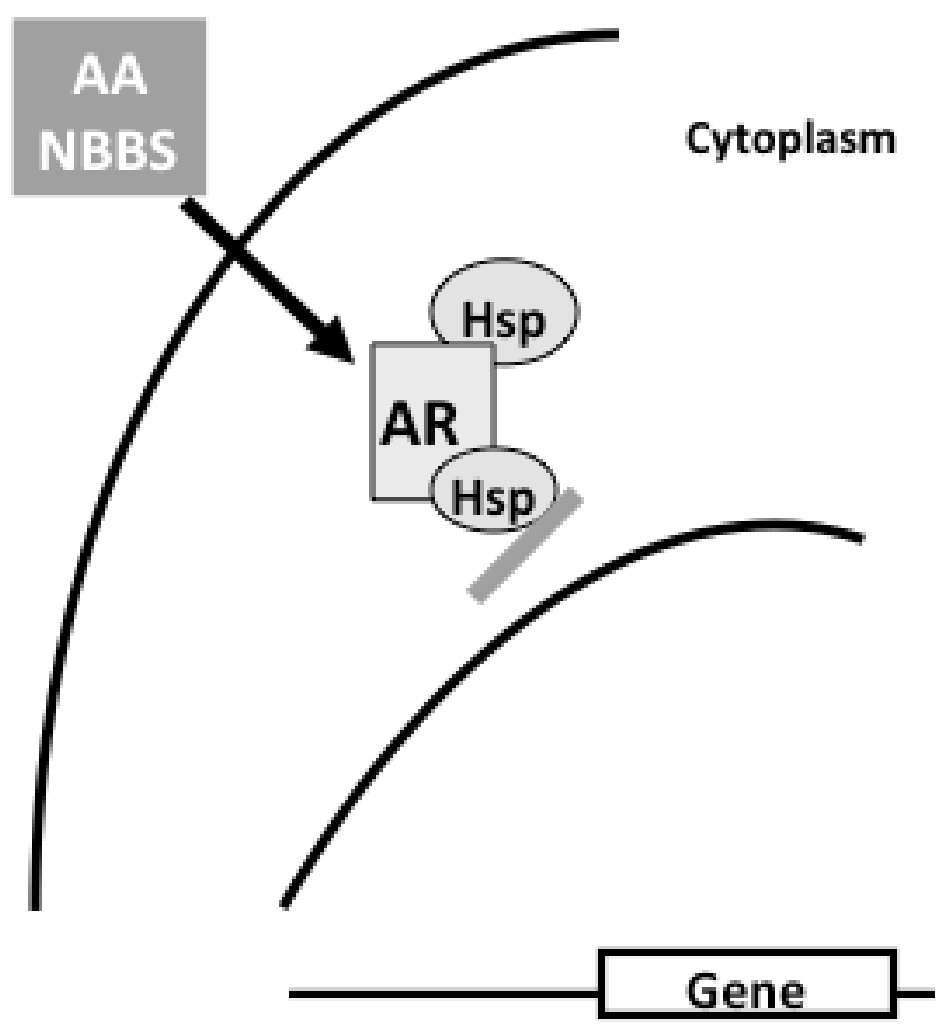

